\title{
A frameshift insertion in the cone cyclic nucleotide gated cation channel causes complete achromatopsia in a consanguineous family from a rural isolate
}

\author{
Cecilia V Rojas ${ }^{*},{ }^{1}$, Lorena Santa María ${ }^{1}$, José Luis Santos ${ }^{1}$, Fanny Cortés ${ }^{1}$ and \\ María Angélica Alliende ${ }^{1}$
}

${ }^{1}$ INTA, Universidad de Chile, Casilla 138-11, Santiago, Chile

Complete achromatopsia is genetically heterogeneous and segregates with mutations in CNGA3 or CNGB3 genes, which respectively encode for $\alpha$ - and $\beta$-subunits of the cyclic-nucleotide-gated (CNG) cation channel expressed in cone photoreceptors. High incidence of the disease (1 in 60) was detected in a rural isolate in central Chile. We excluded previously reported mutations in a consanguineous kindred with five affected members. Genotype analysis with short tandem repeat polymorphic (STRP) markers provided evidence to search for the causative mutation in CNGB3. Two sequence variations, c.492_493ins T and c.488A $>G$, flanking an adenosine $\left(A_{5}\right)$ repeat in exon 4 were identified. The frameshift mutation creates two consecutive stop codons in exon 5 that would induce premature translation termination. The severely truncated $\beta$-subunit is likely to render a nonfunctional cone CNG channel and cause total colour blindness in this kindred.

European Journal of Human Genetics (2002) 10, 638 - 642. doi:10.1038/sj.ejhg.5200856

Keywords: complete achromatopsia; ACHM3; colour blindness; mutation analysis; CNGB3; CNG channel

\section{Introduction}

Complete achromatopsia (total colour blindness; ACHM3; OMIM 262300) is an autosomal recessive disease with an estimated incidence of $1: 30000,{ }^{1}$ characterised by total inability to distinguish colours, reduced visual acuity, photophobia and nystagmus. The disease was genetically mapped to chromosome 2q11.2-q12 (ACHM2 locus) ${ }^{2,3}$ and chromosome 8q21-q22 (ACHM3 locus), ${ }^{4,5}$ which comprise $C N G A 3$ and $C N G B 3$ genes, respectively. Mutations in the genes for the $\alpha$-subunit (CNGA3) and $\beta$-subunit (CNGB3) of the $\mathrm{CNG}$ channel expressed in cones are the primary cause of complete achromatopsia in families with diverse geographic or ethnic origin. ${ }^{6-9}$

Mutation analysis of affected members from a consanguineous family resident in a rural isolate in central Chile with high disease incidence $(1: 60),{ }^{10}$ allowed us to exclude all previously reported $C N G A 3$ or $C N G B 3$ mutations in these

\footnotetext{
*Correspondence: CV Rojas, INTA, Universidad de Chile, Casilla 138-11, Santiago, Chile. Tel: (56 2) 678 1421; Fax: (56 2) 221 4030;

E-mail: crojas@uec.inta.uchile.cl

Received 28 January 2002; revised 1 June 2002; accepted 7 June 2002
}

subjects. Homozygosity of STRP markers for the ACHM3 locus prompted us to search for the underlying genetic defect in CNGB3. We identified two close nucleotide changes that segregate with the disease, a transition and a single nucleotide insertion. The frameshift insertion, that would cause premature translation termination, is likely responsible for complete achromatopsia in this kindred.

\section{Materials and Methods \\ Subjects}

Ten subjects of Hispanic descent from a rural isolate of 600 inhabitants were diagnosed with complete achromatopsia. These patients exhibited complete inability to discriminate colours, reduced visual acuity $(<0,2)$, nistagmus, and photophobia. Clinical symptoms were evident in early childhood. Fundus examination revealed atrophic macular changes in two older patients. Electroretinographic examination carried in two patients showed reduced cone photopic flicker response.

Personal interviews and records from the local government were used to establish family relationships for 82 individuals and to construct the family pedigree accounted 
for in this study (Figure 1). Peripheral blood was obtained after informed consent from eight available subjects, five affected and three healthy relatives. This research project was approved by the Ethics Committee at INTA, Universidad de Chile.

\section{Genotype analysis with STRP markers}

Genomic DNA isolated from white cells by standard phenolchloroform procedure was used for genotyping with STRP markers D2S2333, D2S113 and D2S2264 on 2q11-q12 and D8S1119, D8S1707, D8S167, D8S273 on 8q21- q22. Marker amplification was carried out by PCR and analysed by denaturing polyacrylamide electrophoresis (see Appendix).

\section{Linkage analysis}

We used a modified version of the MLINK 4.03 programme $^{11}$ compiled for analysis of pedigrees with up to seven consanguinity-loops. An autosomal recessive model of inheritance with no phenocopies and complete penetrance was assumed. The frequency of the disease-causing allele was set to 0.13 , reflecting the approximate frequency of the disease in this community. To reduce the computational burden of multipoint linkage analysis, the entire 8q21-q22 haplotype was recoded into a single three-allele marker system, assuming no recombination among such markers.

\section{Mutation screening}

Coding exons and intron-exon boundaries were PCRamplified using primers within flanking introns. At least three independent reactions per amplicon were pooled for sequence analysis using an ABI model 377 DNA sequencer. Mutations were verified on both DNA strands (see Appendix).

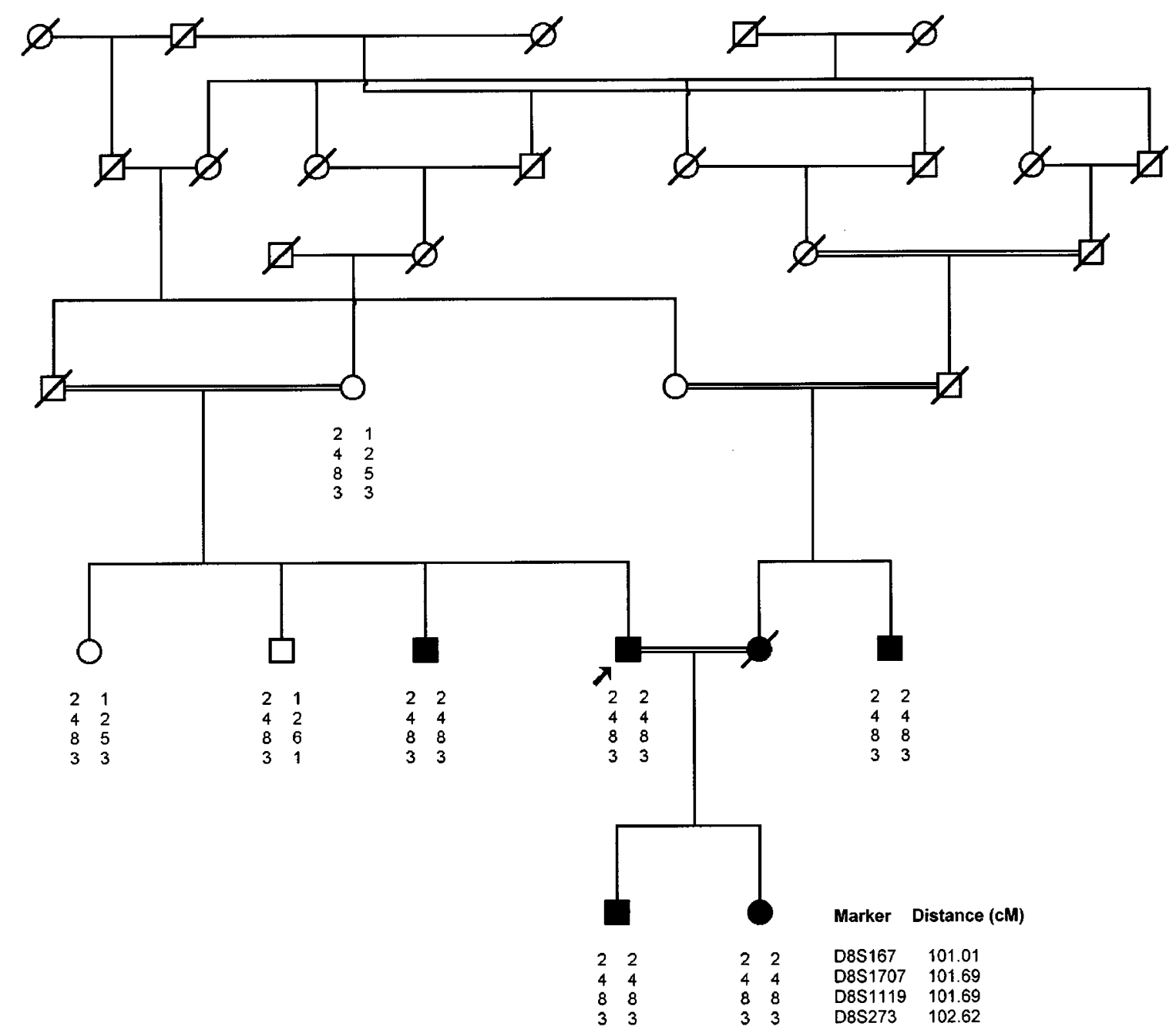

Figure 1 Pedigree of the family with complete achromatopsia. Genotyping data for 8q21-q22 STRP markers are given below individuals available for analysis. The markers are ordered from centromere to telomere. The arrow indicates the proband. 
A

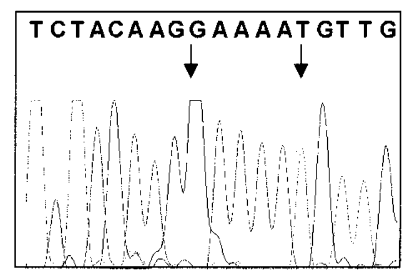

Homozygous

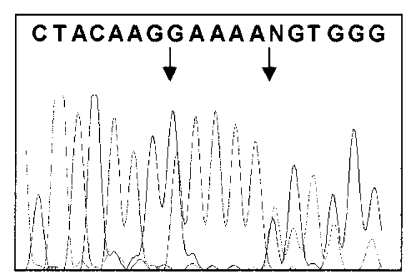

Heterozygous

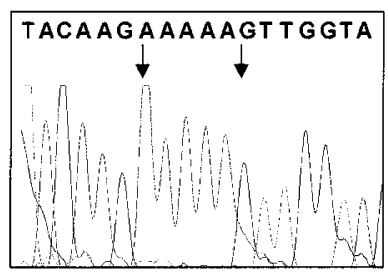

Wildtype sequence

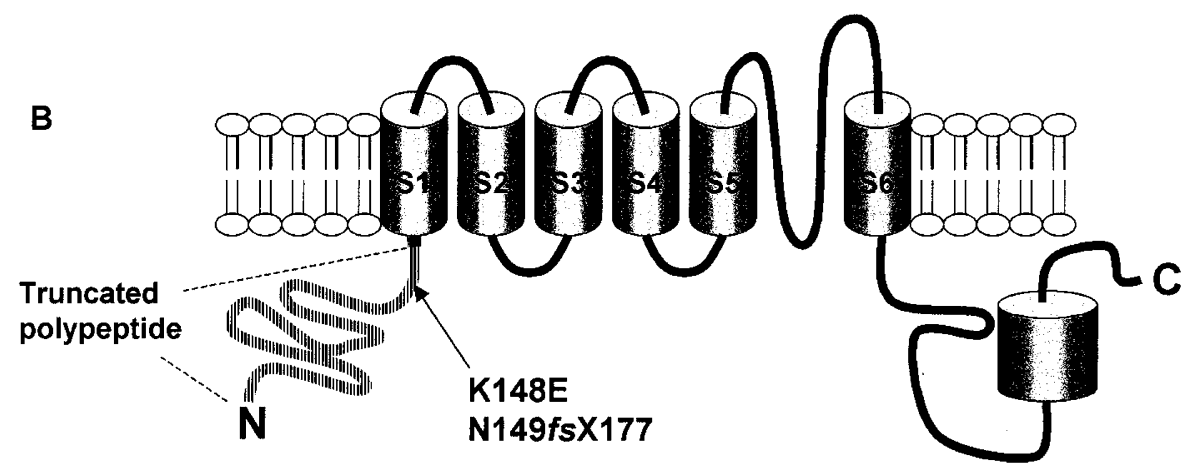

Figure 2 (A) Electropherogram sections of exon 4 sequence around the A5 repeat for homozygous, heterozygous and wildtype subjects. (B) Folding model for cone CNG $\beta$-subunit. The arrow indicates the approximate position of the changes in protein sequence.

\section{Results}

Five affected subjects and three unaffected siblings (Figure 1) were genotyped to define whether the disease segregates with genetic markers for the ACHM2 or ACHM3 loci in this family. ACHM2 markers failed to display any haplotypephenotype association. Conversely, all patients showed homozygosity for D8S167, D8S1707, D8S1119 and D8S273 markers spanning a $1.6 \mathrm{cM}$ interval in 8q21-q22. Whereas, their unaffected siblings were heterozygous. Constructed haplotypes for chromosome 8q21 markers are shown in Figure 1.

Given that allele frequencies for these STRP markers are unknown in this population and that LOD score analysis may be influenced by incorrect specification of such frequencies, ${ }^{12}$ either equal allele frequency for each marker or allele frequencies drawn from public databases were assumed to compute LOD scores. The frequency of the linked haplotype (2-4-8-3) was set equal to the frequency of the least frequent allele in the haplotype. Under these conditions, LOD scores of 2.15 (equal allele frequency) and 2.74 (allele frequency from databases) were calculated.

Sequence analysis of the eighteen exons from the proband (Figure 1) revealed two nucleotide changes in CNGB3, a transition (c.488A $>\mathrm{G}$ ) that results in a $\mathrm{K}$ to $\mathrm{E}$ substitution, and a single frameshift insertion (c.492_493insT) flanking an adenosine $\left(\mathrm{A}_{5}\right)$ repeat in exon 4. All affected individuals were homozygous for both nucleotide changes; whereas heterozygotes displayed the mixed sequence pattern illustrated in Figure 2A. Two unaffected relatives, whose family relationships were not clearly established (consequently, not included in the pedigree), were also heterozygous for the described sequence modifications. The frameshift insertion, not detected in 100 control chromosomes, creates downstream consecutive nonsense codons at positions 178 and 179 .

\section{Discussion}

Evidence for association of complete achromatopsia to the CNGB3 gene in this kindred was provided by homozygosity of all four markers spanning a $1.6 \mathrm{cM}$ interval that encompasses the $C N G B 3$ gene in all affected subjects. Unaffected siblings exhibited heterozygous haplotypes (Figure 1).

Sequencing analysis of $C N G B 3$ exons in the proband lead to the identification of two close nucleotide changes in CNGB3. These sequence modifications were confirmed in all available individuals in this kindred. The c. $488 \mathrm{~A}>\mathrm{G}$ transition causes a missense substitution (K148E) of an amino acid residue, conserved among human and mouse cone CNGB3 subunits, that is located in the protein amino terminus. However, CNGB1 subunits from human, mouse and bovine rods bear glutamic acid in this position. The frameshift insertion (c.492_493T) creates two consecutive nonsense codons in exon 5 that would cause premature termination of protein translation. The truncated polypeptide is only 177-amino acids long and lacks all membrane spanning segments, acccording to the folding model (Figure 
2B). Therefore, it is highly likely that complete achromatopsia in this kindred arises from loss of CNGB3 function attributable to the single base insertion (c.492_493insT).

This family, with four consanguineous marriages, belongs to a community with a high inbreeding coefficient. ${ }^{10}$ Conceivably, the disease mutation was spread among family members and other inhabitants of the rural isolate due to consanguinity.

\section{Acknowledgements}

We are grateful to family members for their participation in this study, and also to Dr Juan Verdaguer for clinical diagnosis and Dr Lodewijk Sandkuilj (Leiden University Medical Center, Leiden, The Netherlands) for providing a modified version of the MLINK programme and for his helpful comments. We also acknowledge Marisol Blanco for technical assistance. This work was supported by a grant DID-SAL13. Lorena Santa María is a Fellow from CONICYT.

\section{References}

1 Jäger W: Genetics of congenital colour deficiencies; Autrum VH, Jung R, Loewenstein D (eds): Handbook of Sensory Physiology. Heidelberg: Springer; 1972; pp 625-669.

2 Arbour NC, Zlotogora J, Knowlton R et al: Homozygosity mapping of achromatopsia to chromosome 2 using DNA pooling. Hum Mol Genet 1997; 6: 689-694.

\section{Appendix}

\section{Methods supplement}

Genotype analysis with short-tandem-repeat polymorphic (STRP) markers Genomic DNA was isolated from blood white cells according to a standard procedure. ${ }^{1}$ STRP markers spanning $10.3 \mathrm{cM}$ on human $2 \mathrm{q} 11-\mathrm{q} 12$ and $1.6 \mathrm{cM}$ on human 8q21-q22 were used for genotyping of individuals. Amplification of STRP markers by standard PCR was carried out with 50 ng of genomic DNA in $25 \mu \mathrm{l}$ of PCR buffer (20 mM Tris $\mathrm{HCl} \mathrm{pH} \mathrm{8.4,50} \mathrm{mm} \mathrm{KCl}$ ), $1.5 \mathrm{mM} \mathrm{MgCl}_{2}, 0.2 \mathrm{mM}$ each dNTP, $1 \mu \mathrm{M}$ of the forward and reverse primers and 0.6 U Taq DNA polymerase (Life Technologies, Rockville, MD, USA). PCR primer sequences for D8S1119, D8S1707, D8S167, D8S273, D2S2333, D2S113 and D2S2264 amplimers were obtained from The Genome Database. The PCR program for STRP marker D8S1707, D8S273, D2S2264 amplification consisted of 34 cycles of $94^{\circ} \mathrm{C}$ for $40 \mathrm{~s}, 60^{\circ} \mathrm{C}$ for $60 \mathrm{~s}$ and $72^{\circ} \mathrm{C}$ for $60 \mathrm{~s}$, followed by a single cycle of $94^{\circ} \mathrm{C}$ for $40 \mathrm{~s}, 60^{\circ} \mathrm{C}$ for $60 \mathrm{~s}$ and $72^{\circ} \mathrm{C}$ for $10 \mathrm{~min}$. The cycling parameters for STRP D8S167 and D2S2333 markers were 34 cycles of $94^{\circ} \mathrm{C}$ for $40 \mathrm{~s}, 58^{\circ} \mathrm{C}$ for $60 \mathrm{~s}$ and $72^{\circ} \mathrm{C}$ for $60 \mathrm{~s}$, followed by a single cycle of $94^{\circ} \mathrm{C}$ for $40 \mathrm{~s}, 58^{\circ} \mathrm{C}$ for $60 \mathrm{~s}$ and $72^{\circ} \mathrm{C}$ for $10 \mathrm{~min}$. Amplification of STRP D8S1119 and D2S113 markers consisted of 34 cycles of $94^{\circ} \mathrm{C}$ for $40 \mathrm{~s}, 63^{\circ} \mathrm{C}$ for $60 \mathrm{~s}$ and $72^{\circ} \mathrm{C}$ for $60 \mathrm{~s}$, followed by a single cycle of $94^{\circ} \mathrm{C}$ for $40 \mathrm{~s}$,
3 Wissinger B, Jägle $\mathrm{H}$, Kohl S et al: Human rod monochromacy: linkage analysis and mapping of a cone photoreceptor expressed candidate gene on chromosome 2q11. Genomics 1998; 51: 325 331.

4 Milunsky A, Huang XL, Milunsky J, DeStefano A, Baldwin CT: A locus for autosomal recessive achromatopsia on human chromosome 8q. Clin Genet 1999; 56: 82-85.

5 Winick JD, Blundell Ml, Galke BL, Salam AA, Leal SM, Karayiorgou M: Homozygosity mapping of the achromatopsia locus in the Pingelapese. Am J Hum Genet 1999; 64: 1679-1685.

6 Kohl S, Marx T, Gidding I et al: Total colourblindness is caused by mutations in the gene encoding the $\alpha$-subunit of the cone photoreceptor cGMP-gated cation channel. Nature Genet 1998; 19: $257-259$.

7 Sundin OH, Yang JM, Li Y, Zhu D, Hurd JN: Genetic basis of colourblindness among the Pingelapese islanders. Nature Genet 2000; 25: 289-293.

8 Kohl S, Baumann B, Broghammer $\mathrm{M}$ et al: Mutations in the CNGB3 gene encoding the $\beta$-subunit of the cone photoreceptor cGMP-gated channel are responsible for achromatopsia (ACHM3) linked to chromosome 8q21. Hum Mol Genet 2000; 9: 2107-2116.

9 Wissinger B, Gamer D, Jägle H et al: CNGA3 mutations in hereditary cone photoreceptor disorders. Am J Hum Genet 2001; 69: $722-737$.

10 Cortés F, Alliende MA, Verdaguer J, Frías D: Analysis of an isolated population with high incidence of Achromatopsia: Inbreeding coeficient and clinical diagnosis. Rev Brasil Genet 1992; 15: 112.

11 Lathrop GM, Lalouel JM, Julier C, Ott J: Strategies for multilocus analysis in humans. Proc Natl Acad Sci USA 1984; 81: 3443-3446.

12 Freimer NB, Sandkuijl LA, Blower SM: Incorrect specification of marker allele frequencies: effects on linkage analysis. Am J Hum Genet 1993; 52: 1102-1110.

$63^{\circ} \mathrm{C}$ for $60 \mathrm{~s}$ and $72^{\circ} \mathrm{C}$ for $10 \mathrm{~min}$. Amplimers were separated by electrophoresis on 6 or $8 \%$ polyacrylamide- $8 \mathrm{M}$ urea gels, according to Bassam. ${ }^{2}$

Screening for previously reported mutations in CNGA3 and CNGB3 Coding exons and intron-exon boundaries were PCR-amplified from genomic DNA isolated from affected individuals with primers located within flanking introns. Primer sequences for amplification exon 4 through 18 on $C N G B 3$ were from Sundin et al. ${ }^{3}$ Primers designed for amplification of CNGB3 exons 1, 2 and 3 and CNGA3 exons 5 and 7 are indicated in Table 1. Amplification reactions were carried out as described above. PCR programmes consisted of 32 cycles $\left(94^{\circ} \mathrm{C}\right.$ for $60 \mathrm{~s} ; 53^{\circ} \mathrm{C}$ for $150 \mathrm{~s} ; 72^{\circ} \mathrm{C}$ for $60 \mathrm{~s}$ ) followed by a single cycle $\left(94^{\circ} \mathrm{C}\right.$ for $60 \mathrm{~s} ; 53^{\circ} \mathrm{C}$ for $60 \mathrm{~s} ; 72^{\circ} \mathrm{C}$ for $\left.10 \mathrm{~min}\right)$ for $C N G A 3$ exons 5 and 7 , and 35 cycles $\left(94^{\circ} \mathrm{C}\right.$ for $40 \mathrm{~s} ; 63^{\circ} \mathrm{C}$ for $60 \mathrm{~s} ; 72^{\circ} \mathrm{C}$ for $40 \mathrm{~s}$ ), followed by an extension cycle $\left(94^{\circ} \mathrm{C}\right.$ for $40 \mathrm{~s} ; 63^{\circ} \mathrm{C}$ for $60 \mathrm{~s} ; 72^{\circ} \mathrm{C}$ for $\left.10 \mathrm{~min}\right)$, for CNGB3 exons 5, 6, 9, 10, 11 and 13. At least three independent reactions per amplicon were pooled and fractionated by electrophoresis on $2 \%$ agarose gels in TAE buffer. DNA fragments were recovered from agarose using QIAquick Gel Extraction Kit (Qiagen Inc., Valencia, CA, USA) and quantitate spectrophotometrically. Sequen- 
Table 1 Primer sequence used for CNGA3 and CNGB3 mutation screening

\begin{tabular}{lccc}
\hline $\begin{array}{l}\text { Target } \\
\text { gene }\end{array}$ & Amplicon & $\begin{array}{c}\text { Primer } \\
\text { name }\end{array}$ & Primer sequence \\
\hline CNGB3 & exon 1 & B-E1F & GGCACAGTCATAAATACAGAGG \\
& & B-E1R & CATGTACCAGATGGTGCCAGG \\
CNGB3 & exon 2 & B-E2F & GATCTGATTGACAATTAAGTGG \\
& & B-E2R & CTAGATAATTCACCTAGTCAAGG \\
CNGB3 & exon 3 & B-E3F & CATCTTGTAGCTCATGTTCCC \\
& & B-E3R & ATTCAGCTAAAGGGGAGAGTGG \\
CNGA3 & exon 5 & A-E5F & GAAGCGCCTGGCCCTGGCC \\
& & A-E5R & CCTGCAAATAAGCAGATACC \\
CNGA3 & exon 7 & A-E7F & AAAGGTGGCACAACTACC \\
& & A-E7R1 & CAGCCTTCAGCTGTCTGGG \\
& & A-E7R2 & CCTTGAGAGGCAGAACAGG \\
& & A-E7R3 & GCGCCCATGCTCTGGGATTG \\
& & A-E7R4 & AAGCAGGAGACAGATGCTGC \\
\hline
\end{tabular}

cing of amplicons was carried out using an ABI model 377 DNA sequencer and compared to the wild type mRNA sequence. Mutations were verified by sequencing with both forward and reverse primers.

Screening a control population for the nucleotide changes in exon 4 Genomic DNA from 50 control individuals with similar ethnic background was screened by standard PCR for the presence of the two sequence changes in exon. Four independent amplification reactions per DNA sample were carried out with primers designed to discriminate between bases $\mathrm{A}$ or $\mathrm{G}$ at nucleotide 488 and $\mathrm{A}$ or $\mathrm{T}$ bases at position 492. Primer pairs and their sequences are listed in Table 2. The amplification products were separated by agarose gel electrophoresis, stained with ethidium bromide and their size compared to appropriate standards.
Table 2 Primer sequences used for CNGB3 SNP screening

\begin{tabular}{lcc}
\hline $\begin{array}{l}\text { Primer } \\
\text { name }\end{array}$ & \multicolumn{1}{c}{ Primer sequence } & $\begin{array}{c}\text { Amplicon } \\
\text { size }(\mathrm{bp})\end{array}$ \\
\hline 488A-F & GCGTCAAAGAACAGCCCTCTACAAGA & 125 \\
E4II-R & CCCCTCAGCACTTCTTTCTTCCCAG & \\
488G-F & GCGTCAAAGAACAGCCCTCTACAAGG & 179 \\
E4-R & TCTCAGGGTCTGCTITGGGAGATCCAA & 178 \\
492A-R & GGTGAGGAGAGATCTCCCTCTACCAACT & 178 \\
E4-F & TCTTCATGGGCCCATCTCTATTGCCA & 110 \\
E4II-F & GCTCCTGTATAAATGAGTATGCCG & 110 \\
492T-R & GAGGAGAGATCTCCCTCTACCAACA & \\
\hline
\end{tabular}

\section{Electronic database information}

The human CNGB3 gene Locus ID 54714, Accession No. NT023717; complete sequence, clone RP11-298P6, Accession No. AC013751; human CNGB3 mRNA, Accession No. AF272900; human CNGB1, Accession No. AI004485; bovine CNGB1, Accession No. AI150392; mouse CNGB3 mRNA, Accession No. NM013927 and mouse CNGB3 mRNA, Accession No. AJ243572, were from GenBank: http:/www.ncbi.nlm.gov Allele frequency was obtained from: http://www2.mc.duke.edu/depts/medicine/medgen/ allelefreqs/frequency.html, http://www.gdb.org/gdb-bin/ genera/genera/hgd/Allele, and http://lpg.nci.nih.gov/cgibin/markerSearch

\section{References}

1 Medrano J, Aasen E, Sharrow L: DNA extraction from nucleated red blood cells. Biotechniques 1990; 8: 43.

2 Bassam BJ, Caetano-Anolles G, Gresshoff PM: Fast and sensitive silver staining of DNA in polyacrylamide gels. Anal Biochem 1991; 196: 80-83.

3 Sundin OH, Yang JM, Li Y, Zhu D, Hurd JN: Genetic basis of colourblindness among the Pingelapese islanders. Nature Genet 2000; 25: $289-293$. 